\title{
3
}

\section{Orient as Woman, Orientalism as Sentimentalism: Flaubert}

La femme orientale est une machine, et rien de plus; elle ne fait aucune différence entre un homme et un autre homme. Fumer, aller au bain, se peindre les paupières et boire du café, tel est le cercle d'occupations où tourne son existence. Quant à la jouissance physique, elle-même doit être fort légère puisqu'on leur coupe de bonne heure ce fameux bouton, siège d'icelle. Et c'est là ce qui la rende, cette femme, si poétique à un certain point vue, c'est qu'elle rentre absolument dans la nature. . . .

$C^{\prime}$ est nous qui pensons à elle, mais elle ne pense guère à nous. Nous faisons de l'esthétique sur son compte.

[The oriental woman is a machine, and nothing more; she doesn't differentiate between one man and another. Smoking, going to the baths, painting her eyelids and drinking coffee, such is the circle of occupations which make up her existence. As for physical pleasure, it must be very slight since they cut off that famous button, the very place of it, quite early on. And for me, this is what renders this woman so poetic, that she becomes absolutely one with nature. . . .

We are thinking of her, but she is hardly thinking of us. We are weaving an aesthetic on her account.]

Gustave Flaubert, "Lettre à Louise Colet," Correspondance

Traveling through Egypt in 1853, Flaubert wrote to his mistress, Louise Colet, about the courtesan Kuchuk-Hânem, describing her thus 
in order to assure Colet that she had no reason for jealousy. This unsettling description of "la femme orientale" is paradigmatic of the intersections of and collusions between several nineteenth-century French discourses, not only of orientalism and romanticism but also of race and industrial capitalism. Like the passage from Flaubert that begins Chapter 1 -the young adulterer's comparison of Emma Bovary's shoulders with those of Ingres's odalisque-the evocation of Kuchuk-Hânem also conflates an eroticized female figure with a stylized orientalist iconography. On one level, Flaubert's use of orientalist and romanticmotifs in the description of Kuchuk-Hânem aestheticizes and elevates a narrative that ultimately subordinates the woman as a sexual object; on another, allusions to the romantic topos of woman as artistic muse obscure the depoliticization of the history of French colonialism in Egypt and North Africa in a tale made innocent of the occidental writer visiting an exotic courtesan. Furthermore, the equation of the oriental woman with the highly prized object of industrialized society, the machine, not only dehumanizes the woman as technology, rendering sexual pleasure the surplus value for which the "femme/machine" is exploited, but also classifies her as racially Other: as machine she is not "human," that is to say, not European; she does not fatigue, does not possess self-consciousness or consciousness of others. "Kuchuk-Hânem" is not merely a locus of orientalism but is represented across a multiplicity of discourses and social relations. She is not a singular object but is variously and heterogeneously projected as at once sexual enchantress, productive machine, and racial inferior. The site of "la femme orientale" responds to a variety of cultural anxieties. Kuchuk-Hânem is a masculine fantasy of pure erotic service in the industrialized age of French imperialism: she generates sexual pleasure, yet she is impassive, undemanding, and insensate herself; her oriental mystery never fails to charm, her resources are never exhausted. ${ }^{1}$

1The nature of the letter as correspondence between Flaubert and Colet is also relevant. Flaubert constitutes Kuchuk-Hânem as the fiction of the woman who has no needs to satisfy. Although ostensibly reassuring Colet that the Egyptian woman means nothing to him (because his relationship with her is merely sexual), Flaubert also derides Colet, implying that Colet is, by contrast, too jealous and demanding. Furthermore, in arguing that the Egyptian woman's insensibility makes her completely different from Colet, a French woman, Flaubert attempts to make Kuchuk the sign and object of exchange between the two occidental correspondents. In constructing women as ma- 
To what cultural anxieties can we say this particular phantasm of the oriental woman responds? In the early nineteenth century France faced a crisis of national identity. The instability of the regimes oscillating between revolution and reaction after 1789; the crisis of class definition in the bourgeois age of rapid industrialization; the changes in family, gender, and social structure in a time of urbanization and emigration-all of these factors shook and destabilized the old regime. There was a new and urgent desire to refigure "the nation," to imagine new forms of national community as well as coherent emblems of that community rather than relying on the older models of religion, monarchy, and dynasty offered by the ancien régime. Benedict Anderson has argued that the modern concept of the nation-state, born in late eighteenth-century Europe with the development of print capitalism, was a historically specific means of imagining social community in response to the erosion of religious and dynastic "verticalities."2 Flaubert's texts are relevant to the nineteenth-century French project of imagining community, for they ironically parody stories about this desire for forms and emblems of the new French nation. For example, the "sentimental education" of Frédéric Moreau and Charles Deslauriers is very much an ironic allegory for French disillusionment and the search for national identity in the period between the July Monarchy and the failed revolutions of 1848 . But Flaubert also observes the French preoccupation with figuring the nation in L'éducation sentimentale (1869) and many of the other texts that constitute (and mock) the standard norms of French culture by constructing oppositions between central sites and the margins, between bourgeois figures and their antifigures. In addition to the oriental woman, which may be Flaubert's antifigure par excellence, a variety of nineteenth-century antifigures-the adulteress, the decadent, the barbarian, the warring mercenary, the prostitute-are situated at the margins of plots, at odds with the social order. They imply, through contrast, the coherence of figures celebrated as emblems of French orthodoxy: the man of letters, the bourgeois doctor, the industrialist, the landowner,

chines, however, Flaubert makes Colet (as addressee, as witness) complicit in her own degradation as a woman, and an uneasy accomplice to his exploitation of KuchukHânem.

2Benedict Anderson, Imagined Communities: Reflections on the Origin and Spread of $\mathrm{Na}$ tionalism (New York: Verso, 1983), esp. chaps. 2 and 3. 
the military officer. Ironically, figuring otherness in order to situate a coherent national bourgeois identity, as Flaubert does, textualizes the desires of French nationalism in an age of instability, as much as this textualizing contributes to, and further determines, the convention of establishing national identity in the projection of otherness. In this sense Flaubert's oriental woman is an antifigure that articulates by negation a profile of desired traits for the nineteenth-century French bourgeois community: as she is insensate, vulgar, and licentious, they are sensitive, bourgeois, and discreet.

Although the desire to locate and identify coherent standards for the national community was partly the result of conflicts between classes and ideologies within the unstable nineteenth-century French state, the concurrent tendency to figure French national identity in terms of "oriental" differences was rooted in French colonial activities: the social and economic intercourse with the French North African colonies of Algeria, Morocco, and Tunisia served to shift and recast the rhetorical modes and logic of existing discourses, inserting different terms for expressing these new concerns with national identity. Nineteenth-century orientalism provided a means of displacing, while obliquely figuring, both domestic instability and colonialist conflicts; orientalism supported a coherent notion of the "nation" - "the one" while subsuming and veiling a variety of other social differences in the figuration of the Orient as Other. ${ }^{3}$ But just as Flaubert's use of the metaphor of the machine to describe Kuchuk-Hânem betrays not only an orientalist concern with Egyptian women but also a fascination with industrial production, the orientalist narratives that attempt to

\footnotetext{
3See Jean-Claude Berchet, ed., Le voyage en Orient: Anthologie des voyageurs français dans le Levant au XIXe siècle (Paris: Robert Laffont, 1985), an anthology of nineteenth-century French travel literature about the Orient. French orientalism at that time included quite diverse literatures, ranging from travel narratives (Chateaubriand's Itineraire de Paris à Jérusalem, et de Jérusalem à Paris, Nerval's Voyage en Orient, and the journals of Maxime du Camp), to the poetic images of the Orient in the verse of Lamartine, Rimbaud, and Baudelaire, to orientalist novels such as Loti's Aziyadé and Flaubert's Salammbô.

The topos of the Orient seized the imagination of nineteenth-century French painters, too: Delacroix painted Arabian battle and hunt scenes, Gérôme depicted Muslims at prayer, and Ingres's paintings portrayed oriental bathers, odalisques, and slaves. The Orient evoked in nineteenth-century literature and art was alternately a powerfully consuming unknown, a forbidden erotic figure, a grotesquely uncivilized world of violence, and a site of incomprehensible difference. In all senses the Orient was always a richly literary space, a place where French culture could inscribe its various myths and preoccupations by invoking imaginary, and culturally different, Others.
} 
project many kinds of social differences in the image of a single Orient register the displacement of these contiguous concerns-with colonialism, race, class, and gender-in the employment of particular rhetorics and motifs.

The role of the Orient in Flaubert's work has been noted in a number of studies of both Flaubert and orientalism. ${ }^{4}$ In particular the Voyage en Orient (1849-1852), an account of Flaubert's travels through Egypt and the Middle East, and Salammbô (1862), his novel set in Carthage after the First Punic War, occupy influential positions in the French tradition of orientalism. I depart, however, from interpretations of Flaubert's orientalism that view his orientalist texts strictly as expressions of French interest in the Orient, just as I depart from traditional literary discussions of Flaubert that would treat his corpus as if it were a single, aesthetically uniform object of study. I observe instead that, particularly from the standpoint of orientalism, Flaubert's work consists of a heterogeneous, uneven set of texts in which the oriental figures are bound up with-and may reanimate some of the structuring themes of-other discourses. On the one hand, his texts enunciate a multiplicity of discourses; even in my brief discussion of Kuchuk-Hânem it is clear that the figure of the Egyptian courtesan is produced at a complicated nexus of distinct contradictions. It is really not possible to isolate a single determining factor. The representation of KuchukHânem as oriental is figured through the discourse about women as much as the representation of her as woman is figured through the capitalist metaphor of the machine; the diverse constructions are inextricably conjoined. On the other hand, the discursive site represented by Flaubert's corpus is also heterogeneous to the degree that we can also identify uneven formations-what we might call dominant figures and emergent critiques of those figures-among the Flaubertian texts. The relationship between these dominant and emergent moments comes to light in the discussion of the differences between the articulation of orientalist logics in the early texts and in the parodic destabilizing of orientalism that emerges in the later Éducation senti-

"See Said, Orientalism; as well as Jean Bruneau Le "conte oriental" de Gustave Flaubert (Paris: Denöel, 1973); Richard Terdiman, Discourse/Counter-Discourse: The Theory and Practice of Symbolic Resistance in Nineteenth-Century France (Ithaca: Cornell University Press, 1985); and Naomi Schor, Breaking the Chain: Women, Realism, and the French Novel (New York: Columbia University Press, 1985). 
mentale. As I shall suggest, orientalism is targeted in L'éducation as being symptomatic of the regressive topos of sentimentality; orientalism as sentimentalism is parodied as a posture of subjective and cultural instability. Thus, my discussion of Flaubert treats the unevenness and reflexivity of his work as an example of discursive multivalence in French orientalism; not only is orientalism a means of figuring a diversity of concerns with social difference, but also the texts are divided and polyvocal, containing orientalist postures as well as critiques of those postures.

The Descending Woman: Kuchuk-Hânem and Salammbô

We find the portraits of Kuchuk-Hânem in the Correspondance and the Voyage en Orient, written during Flaubert's travels to Egypt and the Middle East between 1849 and 1851; Kuchuk-Hânem is said to be the model for the Carthaginian woman in Salammbô, which he wrote after returning from his travels. One of the principal figurations of both Kuchuk-Hânem and Salammbô makes use of the topos of the descending woman. The trope of descent commences rhetorically with a distancing of the oriental woman as elevated and remote, while performing a simultaneous immediacy, rendering her close through particularized descriptions of physical and ornamental details; in this sense the trope of descent is paradoxical, a means through which the oriental woman is represented as both transcendent and material, virginal yet eroticized. Tracing the descending woman through $\mathrm{Sa}$ lammbô and the Voyage en Orient allows me to remark on how the figure both thematizes and upholds ambivalence, and leads me to make some observations about the relationship between this ambivalence and the repetition of the topos.

Flaubert's novel concerns the Carthaginian priestess Salammbô, and Mâtho, the leader of the North African mercenary army, who falls in love with her. Salammbô, the daughter of the Carthaginian ruler Hamilcar, is betrothed by her father to a rival leader. In the story of Mâtho's impossible desire for Salammbô, the oriental woman is distanced as forbidden and inaccessible and yet objectified as the prize or bounty in Mâtho's war against Carthage. The Barbarians' efforts, un- 
der Mâtho's leadership, to penetrate barricaded Carthage, to puncture the city's aqueduct, and to steal the sacred veil of Tanit are concurrent with Mâtho's growing desire for the virgin priestess; the simultaneity of the two conquest themes contributes to the figuration of the oriental city of Carthage as the woman, Salammbô, while the cultural and historical alterity of Carthage as the Orient is figured in the sexual alterity of Salammbô as woman. Salammbô as "oriental woman" is a complicated representation of intersecting inscriptions: she is a forbidden object of desire as well as a material object of exchange, the barricaded city and the virgin priestess, the infinite beauty of la nature, and the sacred, violent oriental world. She is a fiction of European man's Other, represented as the seducer and recipient of Mâtho's desire, as the prey and object of men's social exchange in war, and as a metonym for the wealthy city of Carthage, which starves its mercenary children.

Two separate descriptions of Salammbô's descents emblematize her ambivalent function in the novel as eroticized woman and as object of exchange in war. The first occurs when she enters the courtyard where the mercenary soldiers are feasting at her father's house in his absence. During the feast the soldiers have proclaimed the injustices of the Carthaginian republic, which has neglected to pay them for their labor during the war against Rome. They curse Hamilcar's wealth and power and kill the sacred fish of the Barca family.

Enfin elle descendit l'escalier des galères. Les prêtres la suivirent. Elle avança dans l'avenue des cyprès, et elle marchait lentement entre les tables des capitaines, qui se reculaient un peu en la regardant passer.

Sa chevelure, poudrée d'un sable violet et réunie en forme de tour selon la mode des vierges chananéenes, la faisait paraître plus grande. Des tresses de perles attachées à ses tempes descendaient jusqu' au coins de sa bouche, rose comme une grenade entrouverte. Il y avait sur sa poitrine un assemblage de pierres lumineuses, imitant par leur bigarrure les écailles d'une murène. Ses bras, garnis de diamants, sortaient nus de sa tunique sans manches, étoilée de fleurs rouges sur un fond tout noir. ${ }^{5}$

[Finally she came down the galley staircase. The priests followed her. She proceeded through the cypress avenue, and walked slowly between the tables, where the captains stood back a little as they watched her pass. 
Her hair, powdered with mauve sand, was piled up like a tower in the style of the Canaanite virgins and made her appear taller. Ropes of pearls fastened to her temples fell to the corners of her mouth, rose red like a half-open pomegranate. On her breast was a cluster of luminous stones, iridescent as lamprey's scales. Her arms, adorned with diamonds, were left bare outside a sleeveless tunic, starred with red flowers on a black background.]

In the full passage from which this excerpt is quoted, Salammbô is described in a vertical descent from her hair to her mouth, her breasts, her arms, and finally her ankles. The descriptive gaze of the narrator anatomizes, particularizes, and sequesters isolated parts of Salammbô. The gems of her costume are an ironically conspicuous display of her market value as an object, her significance as Hamilcar's daughter. The attention to the "perles," "pierres lumineuses," and "diamants" of Salammbô's dress mark her as the embodiment of Hamilcar's hoarded wealth, the war chest desired by the mercenaries as she enters the scene. And yet the narration remains at a distance from her; the narrative gaze does not penetrate into the interior of Salammbô but remains fixed on the jewels, textures, and fabrics of her dress. Salammbô, although described in particulars, is not a character in the immediate world of the novel as others might be, but rather a represented figure that calls attention to itself as representation-unknowable, eccentric, and extravagant to the narrator and the soldiers. Salammbô is compared to "un tour," "une grenade," and "une murène"; while the metaphors attempt to capture her, she is nonetheless rendered quite strange by these comparisons. The metaphor of the tower evokes height, but the comparison renders the woman excessively tall and unfamiliar, as if dwarfing the men below. Salammbô is paradoxically distanced and isolated, objectified and desired by the narrative description. "Salammbô" is a figure for ambivalence; she is concrete and worldly, like her gems, but she has a remote, unworldly aspect that resists possession and referentiality.

In a second passage Salammbô descends to greet her father when he returns to Carthage from the war.

Salammbô descendait alors l'escalier des galères. Toutes ses femmes venaient derrière elle; et, à chacun de ses pas, elles descendaient aussi. ... .

Hamilcar s'arrêta, en apercevant Salammbô. Elle lui était survenue 
après la mort de plusieurs enfants mâles. D'ailleurs, la naissance des filles passait pour une calamité dans les religions du Soleil. (pp. 139140)

[Salammbô was then descending the galley staircase. All her women came behind her; and at each step she took, they took one also. ...

Hamilcar stopped when he saw Salammbô. She had arrived unexpectedly after the death of several male children. Besides, the birth of daughters was regarded as a calamity in the religions of the Sun.]

The two descents-the one before the mercenaries, Mâtho, and Narr'Havras, the other before Hamilcar-indicate two valences of the representation of Salammbô as oriental woman. In the first passage she is a remote, inaccessible erotic object; in the second, as she greets her father, she is a material object of exchange, useful only to Hamilcar as wealth to barter. In the first she is beloved, sought, and desired; in the second she is a disdained possession to be exchanged for the best price. The objectification of Salammbô as material property is particularly evident when Hamilcar receives the rumor that his daughter may have lost her virginity to the leader of the Barbarian tribes. Hamilcar's rage at imagining his daughter's violation mixes with his anger over the theft of the sacred veil, as well as his indignation that his properties and riches have been mismanaged in his absence: "Malgré ses efforts pour les bannir de sa pensée, il retrouvait continuellement les Barbares. Leurs débordements se confondaient avec la honte de sa fille" (p. 153). (Despite his efforts to put them out of his mind, he continually thought about the Barbarians. Their debauchery was conflated for him with his daughter's shame). For Hamilcar, his daughter's alleged rape is equal to his discovery that property has been stolen from his home. It is the combined effect of acknowledging all of his losses-his material loss of possessions as well as the loss of ownership of Salammbô, which the hypothetical violation represents to him-which moves Hamilcar to accept the command of the Carthaginian armies against the Barbarian tribes. When Hamilcar enlists the aid of the Numidians, he offers his daughter as bride to the Numidian king Narr'Havras, saying, "En recompense des services que tu m'as rendus, Narr'Havras, je te donne ma fille" (In exchange for your services, Narr'Havras, I give you my daughter). Narr'Havras's gratitude is described: "[Il] eut un grand geste de surprise, puis se jeta sur ses mains qu'il couvrit de baisers" (p. 235) ([He] made a great gesture 
of surprise and then threw himself on his hands, which he covered with kisses). In the economy of war, Salammbô is the prize, the bounty, which is bartered and exchanged between men. Although "ses mains" is somewhat ambiguous in its reference, it is presumably Hamilcar's hands that Narr'Havras kisses; the man is granted the possession of the woman when he kills for another man; through the exchange of Salammbô, the two men are erotically united. ${ }^{6}$ Salammbô is described as being "calme comme une statue, semblait ne pas comprendre" (p. 235) ("calm like a statue, seeming not to understand"). She is the token whose receipt seals the contract whereby the Numidians promise to kill for the Carthaginians.

The descending oriental woman appears also in the Voyage en Orient, in a description of Flaubert's first encounter with Kuchuk-Hânem. Just as Salammbô's two descents embody twin valences of the "oriental woman," this descent, too, is a means of both eroticizing and materializing the oriental woman, of simulating a progression that charts her movement from being a distanced erotic image to being an immediate and particularized anatomy, under the mastering gaze of the narrator-observer.

Sur l'escalier, en face de nous, la lumière l'entourant et se détachent sur le fond bleu du ciel, une femme debout en pantalons roses, n'ayant autour du torse qu'une gaze d'un violet foncé.

Elle venait de sortir du bain, sa gorge dure sentait frais, quelque chose comme une odeur de térébenthine sucrée. . . .

Ruchiouk-Hânem est une grande et splendide créature, plus blanche qu'une Arabe, elle est de Damas; sa peau, surtout du corps, est un peu cafetée. Quand elle s'asseoit de côté, elle a des bourrelets de bronze sur ses flancs. Ses yeux noirs et démesurés, ses sourcils noirs, ses narines fendues, larges épaules solides, seins abondants, pomme. ${ }^{7}$

'In a most interesting manner, in La femme dans les romans de Flaubert: mythes et idéologie (Lyons: Presses Universitaire de Lyon, 1983), Lucette Czyba associates the reduction of Salammbô as an object of exchange with the homoeroticism of war. Czyba suggests that the sadism of war in Salammbô, may be the obverse aspect of erotic bonding between men. Both male eros and thanatos have the common characteristic of excluding women from a closed society of men; the two parts of the war economy are compatible and mutually productive.

${ }^{7}$ Gustave Flaubert, Oeuvres complètes de Gustave Flaubert, vol. 10 (Paris: Club de l'Honnête homme, 1973), pp. 487-88. The name "Kuchuk-Hânem" appears variously and inconsistently in the Voyage and the Correspondance. 
[On the staircase, facing us, with the deep blue of the sky illuminating her, stood a woman in pink trousers, with nothing around her torso but dark violet gauze.

She had just come out of the bath, her firm bosom smelled fresh, something like the odor of sugared turpentine. . . .

Ruchiouk-Hânem is a tall, splendid creature, whiter than an Arab, as she is from Damas; her skin, especially on her body, is a bit coffee colored. When she sits nearby, she has small bronze bulges on her flanks. Her eyes are black and inordinately large, her eyebrows black, flared nostrils, large solid shoulders, abundant breasts, like apples.]

Like Salammbô in her first entrance, Kuchuk-Hânem is paradoxically distanced and rendered immediate, simultaneously inaccessible and eroticized. The violet gauze around her torso is the detail on which this ambivalence turns; the gauze is at once a reference to female modesty and the initial distance between the narrator and the oriental woman (as a parodic representation of the veil that ensures female modesty in Muslim societies), as well as a signifier of eroticism and sexual accessibility, to the extent that the transparent fabric is the only detail mediating the distance between them. As with the descents of Salammbô, the Egyptian woman enters the narrative gaze from an elevated position on the staircase; the distance and elevation render her exotic and strange. There is an allusion to her height as well in "[elle] est une grande et splendide créature." It is not simply her height, however, that marks her as different: she is called a "créature," as if she were another species, not human but animal. Furthermore, her eyes are "noirs et démesurés," and their color and scale seem to make them icons of her difference. After she descends the staircase, the perspective from which the Egyptian woman is regarded changes suddenly to a disturbingly immediate one; now the writer emphasizes her otherness not through the use of distancing metaphors but through the intimacy of the physical and sensual detail in the descriptions of her race and sex. In "quand elle s'asseoit de côté, elle a des bourrelets de bronze sur ses flancs," the perspective of close proximity is utilized both to aestheticize her image and to reduce her anatomized particulars; the very details-"ses sourcils noirs, ses narines fendues, larges épaules solides, seins abondants, pomme" - work to privilege the artist's eye while constituting Kuchuk-Hânem as fragmented ob- 
ject. The description of her skin color-"plus blanche qu'une Arabe ... sa peau, surtout du corps, est un peu cafetée" —enunciates a further dimension of the oriental woman's ambivalence. If, as Christopher Miller suggests, the construction of "blackness" as the negation of "whiteness" is a nineteenth-century trope fundamental to the invention and positioning of the French race, then the "mixed," ambivalent color of Kuchuk-Hânem's coffee-colored skin undoes this constructed opposition, calls the stability of "whiteness" into question. Miller discusses an analogous ambivalence in Baudelaire's poems to Jeanne Duval, his Creole mistress of many years, noting that in the poem "Les Ténèbres," the line "C' est Elle! noir et pourtant lumineuse" (It's she! black and yet luminous) underscores this ambivalent relationship of darkness and light, in which "elle" figures as the hinge between polar opposites of black and white. For Baudelaire, "la dame créole" is also a figure for racial instability, signifying that races are not pure (that, as Miller observes, everything is "créole"), that colors cannot be fixed but are implicated one within the other. ${ }^{8}$

The trope of descent performs a physical elevation and subordination of the oriental woman. Rhetorically it figures her as at once modestly virginal and erotically alluring; Salammbô's transcendence is signified by the priests who accompany her, while her material value is evidenced by the gems and fabrics of her dress. In addition, Flaubert's oriental woman is racially ambiguous: "bronze" — not "white," but not "black" either. In this sense Flaubert's topos of the oriental woman is fundamentally ambivalent, a characteristic of the colonialist stereotype on which Homi K. Bhabha has remarked. ${ }^{9}$ Bhabha argues that the process of ambivalence is central to the colonialist construction of otherness, which vacillates between a reference to what seems to be accepted knowledge and a contradictory space that challenges this reference and makes it necessary to both fix and repeat it. The descending woman in Flaubert signals this irreducible ambivalence.

8See Miller, Blank Darkness, chap. 2.

9See Bhabha, "The Other Question." Bhabha outlines a more psychoanalytically defined argument for the fundamental "ambivalence" underlying the stereotype of otherness. He suggests that the stereotype (for example, the duplicitous Asiatic or the licentious African), is like the fetish described by psychoanalysis, "between what is always 'in place,' already known, and something that must be anxiously repeated. . . . For it is the force of ambivalence that gives the colonial stereotype its currency: ensures its repeatability in changing historical and discursive conjunctures" (p. 18). 
To the degree that the narrative never succeeds in fully mastering or containing her, the oriental woman exceeds narrative and resists objectification; the narrative must thus repeat the trope of descent in the attempt to arrest and contain this excess. Like the name KuchukHânem, which occurs inconsistently in Voyage and Correspondanceappearing as Ruchuk-Hânem, Ruchiouck-Hânem, and then KuchukHânem, as if, despite anxious repetition to ensure its fixity, the name can never be arrested in an identical form-the topos of the descending oriental woman is repeated variously, with different nuances, different emphases. In his discussion of colonialist discourse, Bhabha suggests a convincing analogy between the colonialist stereotype and the psychoanalytic fetish: like the scene of fetishism, the colonialist construction of otherness includes both a reactivation of the material of original fantasy (for fetishism it is the anxiety of castration and sexual difference, for colonialism the condition of racial difference and the absence of racial purity) and a normalization of that difference in terms of a fixing of the fetish object. But rather than identifying an exclusively psychoanalytic ambivalence, as Bhabha would have it, in my reading of the "oriental woman" I locate ambivalence not only in the psychic shuttling between disavowal and fetishism, but also in the unsettled, multiple social conditions that inform the nineteenth-century discursive site on which she is inscribed: not only in the encounter with racial difference that comes from French colonial contact with the Algerian or the Egyptian, but also in the undeniable economic stratification that widens with industrialization, as well as the irrepressibility of sexual difference thrown into new relief by dramatic shifts in the patriarchal social order. These heterogeneous and uneven conditions render the oriental woman a heterogeneous, unstable signifier, in excess of what can be objectified or singularized, and therefore necessitating and inspiring repetition. It is in this sense that the descent of the oriental woman is narrated at least three times in Flaubert's works, as if repetition could fix its ambivalence or arrest the fundamental excess of the spectrum of otherness.

\section{French Barbarians in Salammbô}

Salammbô takes place in 240 B. C., after Carthage's loss to Rome in the First Punic War, and at the moment in which the various North African 
tribes employed as mercenaries by Carthage revolt against the Carthaginian republic; the novel describes the wars between Carthage and these Barbarian tribes. Although Salammbô evokes a world that is historically and geographically different from nineteenth-century France, it is not difficult to recognize similar imperial themes: just as Carthage had been a commercial republic competing with Rome for markets and empire in the western Mediterranean, so too was earlynineteenth-century France an emerging commercial force, threatening and being threatened by Great Britain. Napoleon's defeats by the British echo Carthage's repeated defeats, under Hamilcar and then his son Hannibal, in the First (264 B.C.), Second (218-201 B.C.), and Third (149-146 B.c.) Punic Wars. Moreover, the decline of Carthage had been due as much to its losses to Rome as to the revolt of the Barbarian tribes of North Africa, just as the instability of France after its international losses in the period of bourgeois revolt (1830) was shaken further by the workers' revolts during the revolutions of 1848 .

Yet, although one would expect Flaubert to figure France as its western antecedent the Roman republic, Rome is conspicuously absent from Salammbô, which focuses strictly on the civil war between Carthage and the Barbarians. ${ }^{10}$ The French narratives of imperialism and revolution are displaced in the "oriental" plot of the Carthaginian war. In the sense that Salammbô represents the Barbarians as subjugated members of the empire, these tribes simultaneously figure both internal and external threats to French bourgeois society in the mid-nineteenth century: on the one hand, the volatile and emergent French working class, whose concerns erupted in 1848 , and on the other hand, the North African colonies violently encountered by French armies in the 1830 and 1840 . The extreme brutality of the battle scenes in Salammbô alienates the slaughter of the rioting masses of 1848 onto a very distant historical setting, while at the same time the location of the violence in North Africa curiously "confesses" the French colonial activities in North Africa and Egypt during the first

10In Improvisation sur Flaubert (Paris: Editions de la Différence, 1984), p. 117, Michel Butor suggests that Carthage is "the hidden face of Roman antiquity" at once denied and suppressed by Rome, the precursor of France, and yet signifying Rome, and, by implication, France. In the sense that Carthage is the oriental Other of Rome, the Other of Christianity and classical antiquity, the absenting of Rome decenters Rome as the place of western origin and presents the French tale in oriental disguise. 
half of the nineteenth century. The French occupation and military subjugation of Algeria in the 1830 os and 1840 os, which included systematic massacres of the native populations, is defamiliarized in the portrait of Carthage's commercial and military exploitation of the nomad peoples outside the walls of the city. Internal class violence and external colonialist violence are thus thematized in the novel, but the responsibility for those deeds is lifted from France when the violence is detoured into the oriental world of Carthage and the surrounding Barbarian tribes. A world of war-determined by commercial greed and the desire for empire, and dependent on the occupation of other lands and other peoples-is made remote by the exotic, defamiliarized context of Salammbô.

Even though the apparent center of the novel is the story is Mâtho's romantic quest for Salammbô, the novel is filled with themes of war: the violent subjugation of many races by the Carthaginian republic; the penetration of the walled-in city; war as a system of alliance and enmity among men. The drama that juxtaposes two powerful warring factions against each other looms large: both the Carthaginians and the Barbarians are involved in a frenzy of violence; each group disapproves of the other's violence, and does not recognize that the other community's "barbarism" is thoroughly reflected within its own side. The rhetoric used to describe the two factions equates one with the other; in so doing the novel foregrounds the process by which one group's violence is at once denied and expelled in the image of a threatening and degraded Other. This process of denial and expulsion further alludes to the displacement of French violence-from the massacres in North Africa as well as the suppression of the working-class revolts in 1848-in the novel's own fiction of a historically distant Orient.

The dynamic by which one group is constituted as Other to the hegemonic culture is represented in the description of the nomad peoples who live just outside the walls of Carthage. This description occurs in the context of the Barbarian tribes' approach to the fortifications, as if the perceptions characterized the attitude of the Barbarians toward the nomadic tribes; the passage contains an inventory of the various means by which a group is classified and constituted as Other, or as "outside." The same logic for constituting otherness is then repeated in the passages describing the Barbarians' attitude toward 
the Carthaginians, and in turn the Carthaginians' construction of the Barbarians.

Il y avait en dehors des fortifications des gens d'une autre race et d'une origine inconnue-tous chasseurs de porc-épic, mangeurs de mollusques et de serpents. . . . Leur cabanes, de fange et de varech, s'accrochait contre la falaise comme des nids d'hirondelles. Ils vivaient là, sans gouvernement et sans dieux, pêle-mêle, complètement nus, à la fois débiles et farouches, et depuis des siècles exécrés par le peuple, à cause de leurs nourritures immondes. (pp. 6o-61)

[There were outside the walls people of another race and of an unknown origin-all hunters of porcupines, eaters of shellfish and snakes. . . . Their huts, of mud and seaweed, clung to the sides of the cliff like swallows' nests. They lived there, with neither government nor gods, in disorder, completely nude, simultaneously feeble and wild, and for centuries ostracized by the people because of their impure foods.]

The nomads are described as "d'une autre race," a difference and an exteriority underscored by their position outside the walls of Carthage, and "d'une origine inconnue," beyond Mâtho's people's territory of information and outside their historical narratives of origin. Their dwellings are made of materials that are coded as primitive and natural. They eat prohibited foods considered "immondes" and wild: porcupines, shellfish, snakes. Hayden White discusses the cultural function of the "savage" as a "technique of ostensive self-definition by negation. ... If we do not know what we think 'civilization' is, we can always find an example of what it is not." 11 In a complementary observation, Mary Louise Pratt notes the particular ethnographic tropes that characterize the reports of European anthropologists encountering "primitive" native cultures. ${ }^{12}$ This description of the nomads as "sans gouvernement et sans dieux, pêle-mêle, complètement nus," evokes the tropes of lawlessness, sin, and nakedness, used throughout the eighteenth and nineteenth centuries for constituting the "primitive" as a state of uncivilized nature, prior to language,

\footnotetext{
11Hayden White, "The Forms of Wildness: Archaeology of an Idea," in Tropics of Discourse (Baltimore: Johns Hopkins University Press, 1978), pp. 150-96. See also "The Noble Savage Theme as Fetish" in the same volume.

12Mary Louise Pratt, "Fieldwork in Common Places," in Clifford and Marcus, Writing Culture, pp. 27-50.
} 
religion, and law. In this sense, the novel foregrounds the rhetorical operations for constituting difference and thus thematizes the displacement of French "barbarisms" into a novel about oriental Barbarians.

Carthage's violence toward the Barbarians is described in sensualized, particularized detail, as are the Barbarian tortures of Carthaginians. Both sides are grotesque and "barbaric," neither more so than the other. The rhetorical equality of the descriptions of the two warring groups suggests that one group's sadism is reflected in the brutality of the other; they are twin images of reciprocal violence, aggressively and narcissistically bound each to the other. Carthage's torture of the Barbarians is described:

Les deux milles Barbares furent attachés dans les Mappales, contre les stèles des tombeaux; et des marchands, des goujats de cuisine, des brodeurs et même des femmes, les veuves des morts avec leurs enfants, tous ceux qui voulaient, vinrent les tuer à coups de flèche. On les visait lentement, pour mieux prolonger leur supplice: on baissait son arme, puis on la relevait tour à tour; et la multitude se poussait en hurlant. . . .

Puis on laissa debout tous ces cadavres crucifiés, qui semblaient sur les tombeaux autant de statues rouges. (p. 184)

[The two thousand Barbarians were attached to the stelae of the tombs in the Mappalian quarter; and merchants, kitchen scullions, embroiderers, and even women - the widows of the dead with their childrenall who would, came to kill them with their arrows. The arrows were aimed slowly at them, in order to prolong their torture, lowering the weapon and then raising it in turn; and the multitude pressed forward howling. ... .

Then all these crucified corpses were left upright, looking like so many red statues.]

The description records in telling detail the carnality of the Carthaginians' sadism: that the torturers include women and children, that they aim their arrows slowly, that the corpses are left standing as monuments to their bloody demise-all these details signify the extremity and excess of the Carthaginians at war. The acts of the Barbarian troops are likewise described in painful detail:

Les hommes y vinrent ensuite, et ils les suppliciaent depuis les pieds, qu'ils coupaient aux chevilles, jusqu'au front, dont ils levaient des cou- 
ronnes de peau pour se mettre sur la tête. . . . Il envenimaient les blessures en y versant de la poussière, du vinaigre, des éclats de poterie: $\mathrm{d}$ 'autres attendaient derrière eux; le sang coulait et il se réjouissaient comme font les vendangeurs autour des cuves fumantes. (p. 241)

[The men came next and tortured them from from their feet, which they cut off at the ankles, to their foreheads, from which they took off crowns of skin to put upon their own heads. . . They envenomed the wounds by pouring into them dust, vinegar, and fragments of pottery; others waited behind them; blood flowed, and they rejoiced like vintagers around steaming vats.]

Like the Carthaginians, among whom gleeful merchants make profits by selling arrows to the crowds, the Barbarians who put vinegar and irritants in the soldiers' wounds are described as being as joyful as wine makers. The narratives in both passages treat each community's sadism, and in the detailed descriptions of the extravagance of their acts, both factions are implicitly condemned; both sets of torturers are unmoved by their own violence and the suffering of others. Similar descriptions of brutality are also present in the descriptions of the slaughter of soldiers and workers during the June battles of 1848 in L'éducation sentimentale; this parallel suggests that the battles scenes in Salammbô are thinly veiled statements about the failures, and loss of human life, in 1848 , whereas the location of these battles in a historically distanced North Africa reveals the preoccupation with, and unsuccessful denial of, the French massacres in North Africa. As an allegory of the battles between the French workers and the bourgeois army in 1848, neither faction is privileged; in Salammbo the workers' revolts are as cynically condemned as they are in L'éducation sentimentale. The novel levels the two sides in the conflict between Carthage and the Barbarians, making each equally barbaric, as if confirming that nationalism and war depend not only on the displacement of one's own barbarism onto another community but also on the inability to recognize the other community's crimes as similar to one's own. Ultimately, the manner in which Carthage constitutes the Barbarians as sacrilegious and violent and the Barbarians consider Carthage to be cruel and hoarding are themselves emblems of the process by which the oriental world of Salammbô is produced, and enjoyed as a spectacle of displaced "barbarism," by the novel itself. 


\section{Oriental Motifs and Sentimentalism: L'éducation sentimentale}

I have suggested that Flaubert's corpus contains a variety of texts for which oriental difference is the structuring trope, but within which other kinds of social differences are figured and elaborated. These texts reflect the shifting and antagonistic nature of the nineteenthcentury culture in which they were produced, and which they, in turn, helped to produce. As cultural products Flaubert's texts are inscribed by a variety of discursive formations, just as a multiplicity of ideological strains compete within the culture; in this sense the orientalism in Flaubert's texts is divided and plural, expressing a variety of often contradictory concerns. For example, Flaubert may have traveled to and written about the Orient as an attempt to escape from bourgeois society and to find a position from which to criticize French society; the appearance of the Orient in his work is thus one representation of cultural self-criticism, of an antibourgeois position. ${ }^{13}$ But the figurations of the oriental otherness in Flaubert's texts equally textualizeeven if only to parody - the cultural preoccupation with defining a coherent national identity, and a bourgeois identity, at a moment when stability was being challenged by class dislocations during and following the revolutions of 1848 , by changing definitions of gender and family in a time of accelerated industrialization and urbanization, and by encounters with racial difference in colonial North Africa. Like the unsettled nineteenth-century cultural moment of which it is a product, Flaubert's work expresses a variety of contradictory ideologies, articulated by both dominant and emergent discursive formations. Moreover, in addition to the multiplicity of ideological positions represented, the narrative styles of the texts are themselves ironic and divided in complex ways. In L'éducation sentimentale (1869), for example, the "style indirect libre," for which Flaubert is so famous, merges narratorial and subjective modes to achieve the greatest elimination of distance between narrator and character. ${ }^{14}$ The result is a subtly ironic

${ }^{13}$ This interpretation of Flaubert's orientalism is offered in Terdiman, Discourse/Counter-Discourse, pt. 2, chap. 5 .

${ }^{14}$ The discussions of Flaubert's style are many. For particularly lucid explications, see Roy Pascal, The Dual Voice: Free Indirect Speech and Its Functioning in the Nineteenth-Century European Novel (Manchester: Manchester University Press, 1977); and Dominick LaCapra, "Madame Bovary" on Trial (Ithaca: Cornell University Press, 1982). 
narrative that in one description preserves the subjective perspective of Frédéric's thoughts as it simultaneously represents a narratorial commentary and critique of that perspective through mimicry of Frédéric's idiom, and through the ironic juxtaposition of different contexts in which this idiom occurs. Thus, whereas Frédéric has a penchant for oriental symbols, and orientalism is present in L'éducation as an aspect of Frédéric's world, at the same time we see that the orientalist posture that associates the Orient with eroticism is established in the narrative as Frédéric's posture; and as a mark of Frédéric's sentimentalism the use of the oriental motif is mocked, parodied, and ultimately criticized.

Oriental motifs-a painting of a Turkish odalisque by Ingres, a Chinese parasol, an Egyptian tarboosh-occur in a number of Flaubert's novels as fragments of an exotic world elsewhere, references to oriental contexts eccentric to the scenes in which they are invoked. These motifs accompany, and come to characterize, the young man's erotic interest: Léon imagining he finds in Emma's shoulders "la couleur ambrée de l'Odalisque au bain," the harpist playing "une romance orientale, où il était question de poignards, de fleurs et d'étoiles" during Frédéric's first sight of Madame Arnoux; or the "chaînette d'or" between the ankles of Salammbô seen by Mâtho when she first approaches the group of soldiers. As fragments they quote from the detailed iconographies of other orientalist texts which associate certain motifs with the Orient: nude slaves, daggers, gold ankle chains. They are incomplete, partial quotations, and their fragmentary nature underscores their standing as marks of incompletion, and hence as marks of desire. For example, in Madame Bovary (1857), Léon's imagining of Emma's shoulders as those of the Turkish odalisque in Ingres's painting does not refer to a woman in a Turkish harem. In imagining Emma as Ingres's subject, Léon expresses his desire by invoking an already established association of the oriental and the erotic; the erotic relationship of present lover and absent beloved, and eroticism as the transgression of prohibition and taboo, are expressed in an oriental motif. In addition, Léon's desire for Emma portrays desire as consisting of the quotation of cultural signs; the metaphor of Emma's shoulders as those in Ingres's painting is twice distanced-itself a quotation of an orientalist painting. It signifies orientalism in order to signify erotic desire. Just as Emma learns her posture of desire from popular 
novels, Léon casts this moment of his desire in an orientalist, and equally literary, mode. ${ }^{15}$ Ironically enough, Ingres never traveled to North Africa or the Near East, but acquired the colors and textures for his bathers, odalisques, and Islamic interiors from the eighteenthcentury letters of Lady Mary Wortley Montagu and Montesquieu's Lettres persanes. ${ }^{16}$. In the sense that Ingres received his Orient from literary sources, it is a literary Orient that he painted, and Léon's notion of desire is as literary as that of Emma. The oriental motif is the distinguishing mark of sentimentalism in Flaubert, a sentimentalism that longs for a memory of earlier innocence, an impossible union, a lost wholeness in which European culture is faithfully reflected in its oriental Other. This paradigm of sentimentalism, represented by the oriental motif, is exemplified, critically observed, and ultimately mocked by the cited motifs in L'éducation sentimentale.

The oriental motif, though perhaps not central to L'éducation, emerges nonetheless as the mark that characteristically expresses and initiates Frédéric's erotic desire. The first time Frédéric meets Madame Arnoux aboard the steamboat, a harpistis playing an oriental ballad. The narration of this scene begins: "Il la supposait d'origine andalouse, créole peut-être" ("He imagined her to be of Andalusian origin, maybe Creole"), which establishes the figuration of Madame Arnoux as exotically Other as Frédéric's perceptive mode. The passage describing the oriental melody, though undesignated by a pronoun as belonging to Frédéric, continues his romantic idiom and postures. The throbbing of the boat's engine is so noisy that the harpist must play even louder to compensate: "les battements de la machine coupaient la mélodie à fausse mesure; il pinçait plus fort: les cordes vibraient, et leur sons métalliques semblaient exhaler des sanglots et comme la plainte d'un amour orgueilleux et vaincu" (The throbbing of the engine punctuated the melody as an uneven accompaniment; he plucked harder, the strings vibrated, and their metallic sounds seemed to plaintively cry out the sad story of a proud, defeated love). ${ }^{17}$ Fré-

\footnotetext{
${ }^{15}$ That Emma takes her particular notion of romantic desire from the clichés of popular novels and from the songs she sang in the convent as an adolescent has been noted by many critics, including Victor Brombert, Flaubert (Paris: Seuil, 1971); Jonathan Culler, Flaubert: The Uses of Uncertainty (Ithaca: Cornell University Press, 1974); and Tony Tanner, Adultery in the Novel (Baltimore: John Hopkins University Press, 1979).

${ }^{16}$ Stevens, The Orientalists, p. 17.

${ }^{17}$ Gustave Flaubert, L'éducation sentimentale (Paris: Garnier Flammarion, 1969), p. 41.
} 
déric's adulterous desire for Madame Arnoux is signified, as is Léon's in Bovary, by the quotation of fragments from orientalism; not only is the ballad a fragment, an emblem of incompletion and desire, but in this image the Orient of its origin is also associated with a lost, threatened past. Frédéric's impossible passion for Madame Arnoux is personified in the sobbing sounds of the plucked notes as the musician attempts to be heard over the engine noises. In this image the narrative observes Frédéric's conflation of several kinds of censorship and prohibition: the noises from the engine impinge on the delicate sounds of the ballad, just as the bourgeois Arnoux obstructs Frédéric's passion for Arnoux's wife and, even more grandly, as western industrial society supersedes an earlier oriental age of plenitude and sensuality. Frédéric's plight is dramatized as that of a lost oriental civilization. Desire is figured in a typically romantic opposition: an earlier temporality is juxtaposed with a corrupted present, an unknown plenitude opposed to a known world. The oriental ballad is already tortured and sad; from the first moment, Frédéric's desire for Madame Arnoux is characterized as one of loss and impossibility. His idealization of Madame Arnoux is continually cast as an exaggerated drama about loss, and is underscored by the hyperbolic language used to express his infatuation: "Plus il la contemplait, plus il sentait entre elle et lui se creuser des abîmes. Il songeait qu'il faudrait la quitter tout à l'heure, irrévocablement, sans avoir arraché une parole, sans lui laisser même un souvenir!" (p. 43) (The longer he gazed at her, the more he felt the opening of abysses between the two of them. He reflected that he would have to leave her soon, irrevocably, without having drawn a single word from her, without leaving her a single memory of himself!). The intensity of Frédéric's desire is represented by the growing enormity of the abysses he imagines opening between them; the moment of contact with her is framed entirely by the inevitable subsequent separation. The narrative critically observes Frédéric creating his sublime sentiment for Madame Arnoux by dramatizing her inaccessibility in the inversion of two moments: the future in which Madame Arnoux is gone is substituted for the present moment of contact. She is constituted as already lost, the moment of contact thoroughly desired because it is irrevocably past. The oriental motif is the mark under which Frédéric's sentimentalizing hyperbole takes place. 
The oriental motif occurs at other moments in the novel as well. Frédéric's passion for Madame Arnoux is continually associated with travel to distant oriental lands: he imagines that he and Madame Arnoux will travel to "des pays lointains . . . au dos des dromadaires, sous le tendelet des éléphants" (p. 101) (faraway countries . . . on the backs of camels, under canopies atop elephants), and he dreams of her "en pantalon de soie jaune, sur les coussins d'un harem" (p. 102) (in yellow silk pants, on pillows in a harem). Later, a bawdy party attended by Frédéric and his young friends takes place in "moresque" rooms, where Hussonet speaks the now typical conflation of the erotic and the oriental by suggesting "un raout oriental" (p. 105) (an oriental orgy). When he is not able to attend Madame Arnoux's birthday party, Frédéric selects for her "une ombrelle ... en soie gorge-pigeon, à petit manche d'ivoire ciselé, et qui arrivait de Chine" (p. 112) (an umbrella ... of iridescent colored silk, with a small handle of carved ivory, which had come from China). The motifs are all heterogeneous fragments: camels and elephants, bits of Moorish interiors, a Chinese silk parasol. They are incomplete allusions to disparate orientalisms, and their fragmentary qualities as motifs call attention to their importance as signifiers, and as marks of desire. Furthermore, the orientalist texts themselves, to which these motifs refer, also represent postures of incompletion, ultimately sentimental paradigms that constitute the invented Orient as a sublime ideal, a lost otherness, a time and space removed from the occidental world. The oriental motif calls attention to itself as a signifier that, in effect, does not signify except to signify orientalism (a larger tradition of postures of incompletion). It is an emblem of the desire to signify desire, as if the structure and character of desire were-as Lacan suggests ${ }^{18}$ - a perpetual series of linguistic

\footnotetext{
${ }^{18}$ Lacan's notion of the "signifying chain" is perhaps most clearly articulated in "Agency of the Letter in the Unconscious, or Reason since Freud," in Ecrits, pp. 146-78.

Lacan's subject is situated in and by language, language being the most determining structure in the Symbolic, or social, realm. He discusses signification in the Symbolic as a process in which every signifier corresponds not to a signified but to another signifier: "No signification can be sustained other than by reference to another signification" (p. 150 ). Desire inheres in the chain of signifiers, and more particularly in the incommensurability of word and thing, the failure of metaphoric similitude, and the determined succession of metonymic associations. "It is in the word-to-word connexion that metonymy is based" (p. 156). The metonymic structure, or the connection between signifier and signifier, "permits the elision in which the signifier installs the lack-of-being in the object relation, using the value of 'reference back' possessed by signification in order to
} 
and social postures of incompletion, which does not find its completion in objects but renews itself in the signification of other desiring postures. That the novel represents desire as inhering in the metonymic substitution of one signifying posture for another is echoed in Frédéric's voyage from one love interest to another: from the infatuation with Madame Arnoux to the desire for Rosanette to the interest in Madame Dambreuse. Frédéric's love choices parallel his efforts to rise into the society of the haute bourgeoisie. He wishes to signify himself and his social standing by the possession of women from particular classes (or women possessed by other men of particular classes); his efforts are unsuccessful, and the progress of his desire is the repeated substitution of one woman for another, or one signifying posture for another. Indeed, in a single day, he visits all three women, going from one residence to the next, and on the day of the fateful rendezvous with Madame Arnoux on rue Tronchet, Frédéric makes love with Rosanette "dans le logement préparé pour l'autre" (p. 307) (in the accommodations prepared for the other).

After Frédéric has deserted Rosanette, spurned Madame Dambreuse, and refused finally to consummate his love with a much older Madame Arnoux, the novel ends with his "atrophie sentimentale" (p. 394) (sentimental atrophy). The Revolutions of 1848 have given way to the installation of Louis Napoléon in 1851 . It is not only the young men in the novel who do not achieve their ambitions; their society also fails to realize the ideals of equality and liberty, lost first in 1789 and now again in 1848. Frédéric's disillusionment in love corresponds to the political disillusionment after the virtual restoration of the old structures of wealth and privilege during the Second Empire. The failure of the revolutions and the betrayal of revolutionary ideals by the bourgeoisie is most poignantly figured when Frédéric witnesses the death of his working-class friend Dussardier at the hands of Sénécal, a former revolutionary turned agent de police. Frédéric's long desire for and pursuit of Madame Arnoux is one model of sentimental idealism observed throughout the novel, but the novel also draws an analogy between Frédéric's education in love and the political education of the French society which has suffered two thwarted efforts at revolution-

invest it with the desire aimed at the very lack it supports" (p. 164). The signifier-in this case the oriental fragment-becomes an index of inaccessibility to totalization, or wholeness, the desire for which it repeatedly motivates. 
ary social change. Frédéric's love quest, a process of desire already marked by the loss of the object, is compared to the failure of the revolutions of 1848 to achieve the egalitarian society previously desired and lost in $1789 .{ }^{19} \mathrm{In}$ this metaphor of the young man's sentimentalism and his society's aspirations, the revolution and its political idealism are judged severely.

The oriental motif that marks Frédéric's and Deslauriers's reminiscence of the bordello at the end of the novel provides the final commentary on the oriental figuration of erotic desire. The two friends' remembrance of their first visit to a house of prostitution in 1837 is introduced by an explanation of how the woman who ran the house had come to be called "la Turque": many people believed her to be a Muslim from Turkey, and as this "ajoutait à la poésie de son établissement" (p. 444) (added a bit of poetry to her establishment), she was from that point known as "la Turque." Hearsay embellished the house with an exotic flair, endowing it with an intriguing erotic quality: "Ce lieu de perdition projetait dans tout l'arrondissement un éclat fantastique. On le désignait par des périphrases: 'L'endroit que vous savez,une certaine rue, - au bas des Ponts.' " (p. 445) (This dangerous place enjoyed a remarkable reputation in the whole district. People referred to it with circumlocutions: "You know the place I mean . . . a certain street . . . below the Bridges"). Frédéric and Deslauriers recall that the townspeople would use euphemisms when speaking of the house of prostitution. Ambiguous, nonreferential phrases such as " $\mathrm{l}$ 'endroit que vous savez" were used to signify the prohibited site of sexuality. The oriental motif of "la Turque" does not refer to the woman who manages the house (indeed, she does not appear in their reminiscence), nor does not it refer to Turkey; "la Turque" is the periphrasis, a turning or deferring of meaning, used by the young boys to signify the plenitude of unknown women and sexual practices within the house of prostitution. It is also the motif under which Frédéric and Deslauriers reconstitute the adolescent position of curiosity, still uninterrupted by failure and disillusionment. The remembered scene has value as a reconstructed moment of pure idealism and innocence:

\footnotetext{
${ }^{19}$ For a discussion of historical representation in Flaubert's novel and Marx's Eighteenth Brumaire of Louis Bonaparte, see Hayden White, "The Problem of Style in Realistic Representation: Marx and Flaubert," in The Concept of Style, ed. Berel Lang (Philadelphia: University of Pennsylvania Press, 1979), pp. 213-22.
} 
Frédéric presents a bouquet "comme un amoureux à sa fiancée" (p. 445) (like a lover to his fiancée), and, flustered by the presence of so many women, he ultimately flees. He leaves the establishment of la Turque a virgin, still inexperienced, with all desire and all disappointment ahead of him. The irony of this final scene, in which Frédéric and Deslauriers invoke a lost moment of plenitude, is punctuated by their final declarations: "C'est là ce que nous avons eu de meilleur!" (p. 445)(That was the happiest time we ever had!). In a characteristically romantic strategy, the two friends perform a dialectic of presence and absence, rhetorically substituting a constructed past_- "c'est là"—for their fallen, corrupted present states. The invocation of the house of la Turque as the place where they had their happiest times replaces their condition of loss with a reconstituted plenitude of adolescent virginity. The novel portrays Frédéric in an endless repetition of these desiring postures, marked by the oriental motif as an unsignifying signifier of incompleteness. This final use of the motif suggests Frédéric's ultimate failure to change; although older and more weary-having lived under Louis Philippe, through the revolutions, and now under Napoléon III-Frédéric invokes once more the adolescent oriental motif to recall an earlier state of desire. ${ }^{20}$

The scene in which Frédéric reminisces about the house of la Turque exposes his invention of oriental exoticism as sentimentality. In a sense, the scene offers us a retrospective critique of orientalism within the Flaubertian corpus itself, whereas the earlier descriptions of "la femme orientale" in Voyage, Correspondance, and Salammbô more vividly exemplify the orientalizing posture that both desires and debases its culturally and sexually different object. To the degree that orientalism and sentimentalism are equated in L'éducation, the narrative criticizes the ultimate delusion and romanticism of the orientalist posture. It is as if the various texts in the oeuvre of the author were themselves different orientalist moments on a continuum in which, to ever greater degrees, the narrative calls attention to orientalism as a posture, and ironically contextualizes that posture. With L'éducation, the orientalist

\footnotetext{
${ }^{20} \mathrm{On}$ the failure of romanticism, the prolonging of youth, and the end of the bildungsroman, in L'éducation sentimentale, see Franco Moretti's discussion of the novel in The Way of the World (London: Verso, 1987). On Frédéric's systematic pursuit of failure, and his refusal to mature, produce, or develop, see Pierre Bourdieu, "The Invention of the Artist's Life," trans. Erec R. Koch, Yale French Studies 73 (1987): 75-103.
} 
imagery is no longer performed by the narrative but is instead mocked as a function of the protagonist. In the final reminiscence of a reconstituted ideal moment under the signifier "la Turque," the utility of the oriental motif as sentimentalism is illustrated, just as the reminiscence emphasizes how the oriental motif indeed fails to signify throughout the novel. The narrative's use of the oriental motif to signify Frédéric's sentimentalism is appropriate because the individual paradigm of sentimentalism is structurally similar to the cultural paradigm of orientalism: each substitutes an invented otherness for a present condition of failed self-possession or unstable cultural identity. 